\title{
Kocuria himachalensis sp. nov., an actinobacterium isolated from the Indian Himalayas
}

Correspondence
S. Mayilraj
mayil@imtech.res.in

\author{
S. Mayilraj, ${ }^{1}$ R. M. Kroppenstedt, ${ }^{2}$ K. Suresh ${ }^{1}$ and H. S. Saini ${ }^{3}$ \\ ${ }^{1}$ Microbial Type Culture Collection and Gene Bank (MTCC), Institute of Microbial Technology, \\ Sector 39-A, Chandigarh, 160 036, India \\ ${ }^{2} \mathrm{DSMZ}$ - Deutsche Sammlung von Mikroorganismen und Zellkulturen GmbH, Mascheroder \\ Weg 1b, D-38124 Braunschweig, Germany \\ ${ }^{3}$ Department of Microbiology, Guru Nanak Dev University (GNDU), Amritsar, 143 005, India
}

The genus Kocuria was taxonomically dissected from the genus Micrococcus to accommodate phylogenetically distinct actinobacteria (Stackebrandt et al., 1995). At the time of writing, the genus Kocuria consists of nine species with validly published names: Kocuria rosea (the type species), $K$. varians, K. kristinae (Stackebrandt et al., 1995), K. palustris, K. rhizophila (Kovács et al., 1999), K. polaris (Reddy et al., 2003), K. marina (Kim et al., 2004), K. carniphila (Tvrzová et al., 2005) and K. aegyptia (Li et al., 2006).

Strain $\mathrm{K} 07-05^{\mathrm{T}}$ was isolated from a soil sample collected from Lahaul-Spiti Valley in the Indian Himalayas by the dilution-plate technique on tryptic soy agar medium (TSA; HiMedia) and maintained on glycerol stocks at $-70{ }^{\circ} \mathrm{C}$. The reference strains K. polaris MTCC $3702^{\mathrm{T}}$ and $K$. rosea MTCC $2522^{\mathrm{T}}$ were taken from the Microbial Type Culture Collection and Gene Bank (MTCC), Chandigarh, India.

Colony and cell morphologies were studied according to standard methods (Murray et al., 1994). The Gram reaction was determined using the HiMedia Gram staining kit

The GenBank/EMBL/DDBJ accession number for the 16S rRNA gene

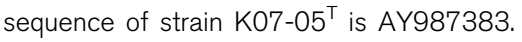

The fatty acid compositions of strain $\mathrm{K} 07-05^{\top}$ and closely related type strains of the genus Kocuria are presented in a supplementary table available in IJSEM Online. according to the manufacturer's instructions. Physiological tests, such as growth at different temperatures, $\mathrm{pH}$ values and $\mathrm{NaCl}$ concentrations, were performed by growing the strains on basal TSA medium. Catalase activity, citrate utilization (using Simmons' citrate agar) and urea hydrolysis were determined as described by Cowan \& Steel (1965). The hydrolysis of casein, gelatin, Tween 80 , tyrosine, starch and indole, the methyl red test, the Voges-Proskauer test and oxidase activity were assessed as described by Smibert \& Krieg (1994). Nitrate reduction was tested as described by Lanyi (1987). The utilization of various carbon compounds as sole carbon sources was tested using Biolog GP2 MicroPlates in accordance with the manufacturer's instructions, except that TSA medium was used instead of Biolog Universal Growth agar medium. The inoculated plates were incubated for $24 \mathrm{~h}$ and the results were read with a MicroPlate Reader using Microlog 4.2 computer software to perform automated reading. The ability to use sole nitrogen sources was studied by using the methods described by Williams et al. (1983), with the modification that agarose $(1.5 \%)$ was used instead of agar. Acid production from various sugars was tested on minimal medium by using the method described by Smith et al. (1952). For cellular fatty acid analysis, the strains were grown on TSA medium at $30{ }^{\circ} \mathrm{C}$ for $36 \mathrm{~h}$; fatty acid methyl ester analysis was performed by using the Sherlock Microbial Identification System (MIDI) as described previously (Pandey et al., 2002). 
Table 1. Phenotypic properties that differentiate strain $\mathrm{K} 07-05^{\top}$ from closely related species of the genus Kocuria

Strains: 1, K07-05 ${ }^{\mathrm{T}} ; 2, K$. rosea MTCC $2522^{\mathrm{T}} ; 3$, K. polaris MTCC $3702^{\mathrm{T}}$. All data are from the present study. None of the strains produces endospores and none is acid-fast; all are positive for catalase activity, growth at $37^{\circ} \mathrm{C}^{a *}, 5 \% \mathrm{NaCl}^{a}$ and $\mathrm{pH} 6 \cdot 5-10$ and acid production from glucose, maltose, mannitol, rhamnose and fructose. All give negative results in the methyl red and Voges-Proskauer tests and are negative for urease, $\mathrm{H}_{2} \mathrm{~S}$ production, hydrolysis of gelatin and casein, growth at $15 \% \mathrm{NaCl}$ and $42{ }^{\circ} \mathrm{C}$ and acid production from galactose ${ }^{a}$, lactose ${ }^{a}$, sorbitol, sucrose ${ }^{a}$, adonitol, dulcitol and cellobiose. In the Biolog GP2 test, all strains are positive for the utilization of dextrin, D-fructose, $\alpha$-D-glucose, maltotriose, D-mannitol, D-mannose, palatinose, D-psicose, D-sorbitol, sucrose, D-tagatose, turanose, D-xylose, acetic acid and adenosine and negative for $\alpha$-cyclodextrin, glycogen, inulin, mannan, Tween $80, \mathrm{~N}$-acetyl-Dglucosamine, $N$-acetyl- $\beta$-D-mannosamine, amygdalin, arabitol, arbutin, L-fucose, D-galactose, gentiobiose, D-gluconic acid, myo-inositol, maltose, D-melezitose, D-melibiose, methyl $\alpha$-D-galactoside, methyl $\beta$-Dgalactoside, methyl $\alpha$-D-glucoside, methyl $\beta$-D-glucoside, methyl $\alpha$-D-mannoside, D-raffinose, L-rhamnose, sedoheptulosan, stachyose, xylitol, $p$-hydroxyphenylacetic acid, $\alpha$-ketoglutaric acid, $\alpha$-ketovaleric acid, lactamide, D-lactic acid methyl ester, L-lactic acid, D-malic acid, pyruvic acid methyl ester, succinic acid monomethyl ester, succinamic acid, succinic acid, $N$-acetyl-L-glutamic acid, L-alaninamide, D- and L-alanine, L-glutamic acid, glycyl L-glutamic acid, L-pyroglutamic acid, putrescine, glycerol, $2^{\prime}$-deoxyadenosine, inosine, uridine, adenosine $5^{\prime}$-monophosphate, thymidine $5^{\prime}$-monophosphate, uridine $5^{\prime}$-monophosphate, D-fructose 6-phosphate, $\alpha$-D-glucose 1-phosphate, D-glucose 6-phosphate and DL- $\alpha$-glycerol phosphate as sole carbon sources. +, Positive; -, negative; W, weakly positive.

\begin{tabular}{|c|c|c|c|}
\hline Characteristic & 1 & 2 & 3 \\
\hline Oxidase & - & $+{ }^{b_{\star}}$ & + \\
\hline Nitrate reduction & - & + & + \\
\hline \multicolumn{4}{|l|}{ Hydrolysis of: } \\
\hline Starch & - & - & + \\
\hline Tween 80 & + & - & + \\
\hline Tyrosine & - & - & + \\
\hline Citrate utilization & - & - & $+{ }^{a}$ \\
\hline \multicolumn{4}{|l|}{ Growth at/on: } \\
\hline $5^{\circ} \mathrm{C}$ & - & - & w \\
\hline $10 \% \mathrm{NaCl}$ & - & - & + \\
\hline $\mathrm{pH} 5 \cdot 2$ & - & - & + \\
\hline \multicolumn{4}{|c|}{ Utilization of substrate as sole carbon source (using Biolog GP2 Microplate) } \\
\hline$\beta$-Cyclodextrin & - & + & - \\
\hline Tween 40 & - & + & - \\
\hline L-Arabinose & + & + & - \\
\hline D-Cellobiose & - & + & - \\
\hline D-Galacturonic acid & - & + & - \\
\hline$\alpha$-D-Lactose & - & - & + \\
\hline Lactulose & - & - & + \\
\hline Methyl-D-glucose & - & + & - \\
\hline D-Ribose & + & + & - \\
\hline Salicin & + & - & + \\
\hline D-Trehalose & - & - & + \\
\hline$\beta$-Hydroxybutyric acid & - & - & + \\
\hline$\gamma$-Hydroxybutyric acid & - & + & + \\
\hline L-Malic acid & - & + & + \\
\hline Propionic acid & - & + & - \\
\hline Pyruvic acid & + & - & - \\
\hline L-Alanyl glycine & - & + & - \\
\hline L-Asparagine & - & + & - \\
\hline L-Serine & - & + & - \\
\hline 2,3-Butanediol & - & + & - \\
\hline Thymidine & - & - & + \\
\hline
\end{tabular}


Table 1. cont.

\begin{tabular}{|c|c|c|c|}
\hline Characteristic & 1 & 2 & 3 \\
\hline \multicolumn{4}{|c|}{ Utilization of substrates as sole nitrogen source } \\
\hline L-Ornithine & + & - & + \\
\hline Histidine & - & $\mathrm{W}$ & - \\
\hline L-Glutamic acid & + & - & + \\
\hline \multicolumn{4}{|c|}{ Acid production from: } \\
\hline Arabinose & - & + & - \\
\hline Glycerol & + & $+{ }^{b}$ & - \\
\hline Xylose & - & - & + \\
\hline Mannose & + & - & - \\
\hline myo-Inositol & - & - & + \\
\hline Melibiose & - & + & + \\
\hline Salicin & - & - & + \\
\hline Trehalose & + & - & W \\
\hline Inulin & - & - & + \\
\hline
\end{tabular}

${ }^{\star}$ Result not in line with data reported in the following studies: $a$, Reddy et al. (2003); $b$, Stackebrandt et al. (1995).

Freeze-dried cells for other chemotaxonomic analyses were prepared following growth of the strains in tryptic soy broth for 4 days at $30{ }^{\circ} \mathrm{C}$. Whole-cell sugars were determined by using the methods described by Staneck \& Roberts (1974). The peptidoglycan structure was determined by using a hydrolysate of purified cell walls, according to Schleifer (1985). The amino acids and peptides were separated by two-dimensional ascending TLC as described by Schleifer \& Kandler (1972), with the modification that TLC on cellulose sheets (Merck 5577) was used instead of paper chromatography. Polar lipids and menaquinones were extracted and analysed by using the methods described by Minnikin et al. (1984) and Kroppenstedt (1982). The absence of mycolic acids was demonstrated by TLC (Minnikin \& Goodfellow, 1976).

Genomic DNA extraction, amplification and sequencing of $16 \mathrm{~S}$ rRNA genes and phylogenetic analysis were performed as described previously (Mayilraj et al., 2005). DNA-DNA hybridization was performed by the membrane filter method (Tourova \& Antonov, 1987). The $\mathrm{G}+\mathrm{C}$ content of the genomic DNA was determined spectrophotometrically (Lambda 35; Perkin Elmer) using the thermal denaturation method (Mandel \& Marmur, 1968).

Strain $\mathrm{K} 07-05^{\mathrm{T}}$ is strictly aerobic and the cells are Grampositive cocci. Colonies are circular, reddish orange in colour and $0.4-3.0 \mathrm{~mm}$ in diameter on TSA medium. Detailed phenotypic properties that differentiate strain K07$05^{\mathrm{T}}$ from closely related species of the genus Kocuria are summarized in Table 1. Most of the chemotaxonomic properties, including the fatty acid composition (presented in the species description and in Supplementary Table S1, available in IJSEM Online) were typical of members of the genus Kocuria. The cell-wall diamino acid was lysine and the interpeptide bridge of the peptidoglycan consisted of three alanine residues (variation A3 $\alpha$; Schleifer \& Kandler, 1972). The almost-complete 16S rRNA gene sequence of strain K07- $05^{\mathrm{T}}$ (1459 bases) was determined. The $16 \mathrm{~S}$ rRNA gene sequence-based phylogenetic analysis revealed that strain $\mathrm{K} 07-05^{\mathrm{T}}$ forms a separate branch within the lineage that includes K. rosea and K. polaris (Fig. 1). The $16 \mathrm{~S}$ rRNA gene sequence similarities for strain $\mathrm{K} 07-05^{\mathrm{T}}$ with respect to K. rosea DSM $20447^{\mathrm{T}}$ and K. polaris MTCC $3702^{\mathrm{T}}$ were respectively $98 \cdot 1$ and $97 \cdot 8 \%$. The similarities with respect to the type strains of the remaining species of the genus were significantly lower $(94 \cdot 2-96 \cdot 4 \%)$. The DNA-DNA hybridization values for strain $\mathrm{K} 07-05^{\mathrm{T}}$ with $K$. polaris MTCC $3702^{\mathrm{T}}$ and with $K$. rosea MTCC $2522^{\mathrm{T}}$ were respectively $49 \cdot 5$ and $24.0 \%$, well below the $70 \%$ cut-off point recommended for the delineation of bacterial species (Wayne et al., 1987).

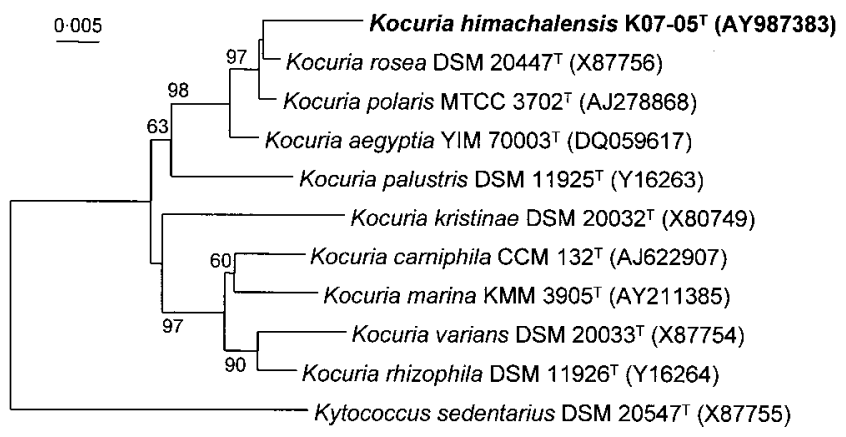

Fig. 1. Neighbour-joining tree, based on 16S rRNA gene sequences (1459 bases), showing the phylogenetic relationship between strain $\mathrm{K} 07-05^{\top}$ and other species of the genus Kocuria. Kytococcus sedentarius DSM $20547^{\top}$ was used as an outgroup. Bootstrap values (expressed as percentages of 1000 replications) greater than $50 \%$ are given at nodes. Bar, $0.5 \%$ sequence variation. 
The levels of DNA-DNA relatedness between strain K07$05^{\mathrm{T}}$ and other Kocuria species were not determined, since it has been shown that organisms with more than $3 \% 16 \mathrm{~S}$ rRNA gene sequence dissimilarity belong to different genomic species (Stackebrandt \& Goebel, 1994). On the basis of the polyphasic data presented above, strain $\mathrm{K} 07-05^{\mathrm{T}}$ should be placed in the genus Kocuria within a novel species, for which we propose the name Kocuria himachalensis sp. nov.

\section{Description of Kocuria himachalensis sp. nov.}

Kocuria himachalensis (hi.ma.cha.len'sis. N.L. fem. adj. himachalensis pertaining to the Indian State of Himachal Pradesh, where the type strain was isolated).

Cells are Gram-positive, coccoid $(1 \cdot 0-1 \cdot 5 \mu \mathrm{m}$ in diameter) and form pairs, tetrads and clusters. Strictly aerobic and non-motile. Colonies are circular, reddish orange in colour and $0 \cdot 4-3.0 \mathrm{~mm}$ in diameter on TSA medium. No growth occurs at 5 or $42{ }^{\circ} \mathrm{C}$. Growth occurs at $20-37^{\circ} \mathrm{C}$ (optimal temperature, $30^{\circ} \mathrm{C}$ ) and $\mathrm{pH} 6 \cdot 5-10$ (optimal $\mathrm{pH}, 7 \cdot 5$ ). Catalase-positive; oxidase test with $N, N, N^{\prime}, N^{\prime}$,-tetramethyl$p$-phenylenediamine dihydrochloride is negative. Does not grow in the presence of $\geqslant 8 \% \mathrm{NaCl}$. Negative for starch hydrolysis, gelatin hydrolysis, citrate utilization, indole production and nitrate reduction and in the methyl red and Voges-Proskauer tests. Hydrogen sulphide is not produced. Substrates utilized as sole carbon sources are given in Table 1. Capable of utilizing L-alanine, L-arginine, Laspartic acid, L-asparagine, L-ornithine, L-glutamic acid, L-lysine and L-phenylalanine; negative for the use of histidine as a sole nitrogen source. Acid is produced aerobically from glucose, glycerol, maltose, mannose, mannitol, rhamnose and trehalose, but not from arabinose, galactose, inulin, lactose, myo-inositol, melibiose, salicin, sorbitol, xylose or sucrose. Peptidoglycan type is Lys- $\mathrm{Ala}_{3}$ (variation $\mathrm{A} 3 \alpha$ ). Whole-cell sugars are glucose, galactose and ribose. Contains major amounts of anteiso-branched $\mathrm{C}_{15: 0}$ $(66 \cdot 16 \%)$ and iso-branched $\mathrm{C}_{15: 0}(15 \cdot 13 \%)$ fatty acids. The major menaquinone is $\mathrm{MK}-8\left(\mathrm{H}_{2}\right)$. The polar lipids are phosphatidylglycerol, diphosphatidylglycerol and two unknown glycolipids. The DNA G $+\mathrm{C}$ content of the type strain is $75 \cdot 3 \mathrm{~mol} \%$.

The type strain, $\mathrm{K} 07-05^{\mathrm{T}}\left(=\right.$ MTCC $7020^{\mathrm{T}}=\mathrm{DSM} 44905^{\mathrm{T}}=$ JCM $13326^{\mathrm{T}}$ ), was isolated from soil $0.45 \mathrm{~m}$ below an ice glacier, $4200 \mathrm{~m}$ above sea level, at Kibber village in Spiti Valley, Himachal Pradesh, India.

\section{Acknowledgements}

We thank Professor Dr Hans G. Trüper (Institute for Microbiology and Biotechnology, Rheinische Friedrich-Wilhelm-University, Bonn, Germany) for his suggestions regarding the Latin nomenclature for the novel species. We would like to thank Ms Gabi Pötter (DSMZ, Braunschweig, Germany) and Mr Ganesan and Mr Malkit Singh for their excellent technical assistance. We also thank the Editor and referees for making useful suggestions. Financial assistance from DBT and CSIR, Government of India, is duly acknowledged. This is IMTECH communication number 13/2005.

\section{References}

Cowan, S. T. \& Steel, K. J. (1965). Manual for the identification of Medical Bacteria. London: Cambridge University Press.

Kim, S. B., Nedashkovskaya, O. I., Mikhailov, V. V., Han, S. K., Kim, K.-O., Rhee, M. S. \& Bae, K. S. (2004). Kocuria marina sp. nov., a novel actinobacterium isolated from marine sediment. Int J Syst Evol Microbiol 54, 1617-1620.

Kovács, G., Burghardt, J., Pradella, S., Schumann, P., Stackebrandt, E. \& Marialigetti, K. (1999). Kocuria palustris sp. nov. and Kocuria rhizophila sp. nov., isolated from the rhizoplane of the narrow-leaved cattail (Typha angustifolia). Int J Syst Bacteriol 49, 167-173.

Kroppenstedt, R. M. (1982). Separation of bacterial menaquinones by HPLC using reverse phase (RP 18) and a silver loaded ion exchanger. J Liq Chromatogr 5, 2359-2367.

Lanyi, B. (1987). Classical and rapid identification methods for medically important bacteria. Methods Microbiol 19, 1-67.

Li, W.-J., Zhang, Y.-Q., Schumann, P., Chen, H.-H., Hozzein, W. N., Tian, X.-P., Xu, L.-H. \& Jiang, C.-L. (2006). Kocuria aegyptia sp. nov., a novel actinobacterium isolated from a saline, alkaline desert soil in Egypt. Int J Syst Evol Microbiol 56, 733-737.

Mandel, M. \& Marmur, J. (1968). Use of ultraviolet absorbancetemperature profile for determining the guanine plus cytosine content of DNA. Methods Enzymol 12B, 195-206.

Mayilraj, S., Prasad, G. S., Suresh, K., Saini, H. S., Shivaji, S. \& Chakrabarti, T. (2005). Planococcus stackebrandtii sp. nov., isolated from a cold desert of the Himalayas, India. Int J Syst Evol Microbiol 55, 91-94.

Minnikin, D. E. \& Goodfellow, M. (1976). Lipid composition in the classification and identification of Nocardia and related taxa. In The Biology of the Nocardiaceae, pp. 160-219. Edited by M. Goodfellow, G. H. Brownell \& J. A. Serrano. London: Academic Press.

Minnikin, D. E., O’Donnell, A. G., Goodfellow, M., Alderson, G., Athalye, M., Schaal, A. \& Parlett, J. H. (1984). An integrated procedure for the extraction of isoprenoid quinones and polar lipids. J Microbiol Methods 2, 233-241.

Murray, R. G. E., Doetsch, R. N. \& Robinow, C. F. (1994). Determinative and cytological light microscopy. In Methods for General and Molecular Bacteriology, pp. 21-41. Edited by P. Gerhardt, R. G. E. Murray, W. A. Wood \& N. R. Krieg. Washington, DC: American Society for Microbiology.

Pandey, K. K., Mayilraj, S. \& Chakrabarti, T. (2002). Pseudomonas indica sp. nov., a novel butane-utilizing species. Int J Syst Evol Microbiol 52, 1559-1567.

Reddy, G. S. N., Prakash, J. S. S., Prabahar, V., Matsumoto, G. I., Stackebrandt, E. \& Shivaji, S. (2003). Kocuria polaris sp. nov., an orange-pigmented psychrophilic bacterium isolated from an Antarctic cyanobacterial mat sample. Int J Syst Evol Microbiol 53, 183-187.

Schleifer, K. H. (1985). Analysis of the chemical composition and primary structure of murein. Methods Microbiol 18, 123-156.

Schleifer, K. H. \& Kandler, O. (1972). Peptidoglycan types of bacterial cell walls and their taxonomic implications. Bacteriol Rev 36, 407-477.

Smibert, R. M. \& Krieg, N. R. (1994). Phenotypic characterization. In Methods for General and Molecular Bacteriology, pp. 607-654. Edited by P. Gerhardt, R. G. E. Murray, W. A. Wood \& N. R. Krieg. Washington, DC: American Society for Microbiology. 
Smith, N. R., Gordon, R. E. \& Clark, F. E. (1952). Aerobic sporeforming bacteria. Agricultural Monograph no. 16. Washington, DC US Department of Agriculture.

Stackebrandt, E. \& Goebel, B. M. (1994). Taxonomic note: a place for DNA-DNA reassociation and 16S rRNA sequence analysis in the present species definition in bacteriology. Int J Syst Bacteriol 44, 846-849.

Stackebrandt, E., Koch, C., Gvozdiak, O. \& Schumann, P. (1995). Taxonomic dissection of the genus Micrococcus: Kocuria gen. nov., Nesterenkonia gen. nov., Kytococcus gen. nov., Dermacoccus gen. nov., and Micrococcus Cohn 1872 gen. emend. Int J Syst Bacteriol 45, 682-692.

Staneck, J. L. \& Roberts, G. D. (1974). Simplified approach to identification of aerobic actinomycetes by thin-layer chromatography. Appl Microbiol 28, 226-231.
Tourova, T. P. \& Antonov, A. S. (1987). Identification of microorganisms by rapid DNA-DNA hybridization. Methods Microbiol 19, 333-355.

Tvrzová, L., Schumann, P., Sedláček, I., Páčová, Z., Spröer, C., Verbarg, S. \& Kroppenstedt, R. M. (2005). Reclassification of strain CCM 132, previously classified as Kocuria varians, as Kocuria carniphila sp. nov. Int J Syst Evol Microbiol 55, 139-142.

Wayne, L. G., Brenner, D. J., Colwell, R. R. \& 9 other authors (1987). International Committee on Systematic Bacteriology. Report of the ad hoc committee on reconciliation of approaches to bacterial systematics. Int J Syst Bacteriol 37, 463-464.

Williams, S. T., Goodfellow, M., Alderson, G., Wellington, E. M. H., Sneath, P. H. A. \& Sackin, M. J. (1983). Numerical classification of Streptomyces and related genera. J Gen Microbiol 129, 1743-1813. 